\title{
Fra de nationale valgs tid i Sønderjylland
}

Af H. Hejselbjerg Paulsen.

De nationale valg i S $\phi$ nderjylland, drs. valgene til den tyske rigsdag og den preussiske landdag, har selvfølgelig fået deres omtale i den foreliggende historiske litteratur. Men ofte ligner behandlingen af emnet mere en efterskrift til valgene eller en oversigt over deres resultat. Det ligger i sagens natur, at disse arbejder - fra tiden f $\varnothing \mathbf{r} 1914$ - må være tidsbestemt præget, og at vigtige sider af den nationalpolitiske problemstilling er ladt ude af betragtning. De opererer $f$. eks. med massive talkolonner og regner meget håndfast med danske og tyske stemmer, som om det var en selvf $\varnothing$ lge, at alle det omtumlede tidligere hertugdømmes beboere uden videre lod sig inddele $i$ disse to kategorier.

Sønderjyske Årbøger har fra sagkyndig hånd en række afhandlinger om de senere valg (f. eks. Nikolaj Andersens i årgangene 1912 ff.), som giver en god oversigt over stillingen og over forskydninger i stemmetallene. Men to vigtige spørgsmál er slet ikke berørt og derfor heller ikke taget op til nærmere unders $\varnothing$ gelse. Og lad det straks være sagt, de kunne og burde vel heller ikke omtales og uddybes nærmere på det tidspunkt. Der tænkes her på en nærmere vurdering af selve valgermassens forhold til dansk og tysk kultur og nationalitet og på en analyse af de såkaldte »blakkedes" store skare, dvs. de mange vielgere, som foretrak at stå som tilskuere til kampen, og som kun undtagelsesvis - f. eks. i 1912 - i større udstrækning af gav deres stemmer. Hvad var det for folk? I hvilke sociale lag hørte de fortrinsvis hjemme? Hvem af de kæmpende parter kunne regne med, at de blandt dem havde en reserve, som kunne aktiviseres og derved blive af afgørende betydning i nationens skæebnetime? 
Dengang var det vel opportunt ikke at røre ved disse spørgsmål, sk $\varnothing$ nt de var levende nok og vakte både bekymring og forhåbning i de ledendes tanker. Nu ligger sagen imidlertid anderledes. Valgene og menneskene bag dem tilh ører nu historiens verden, hvor de nysgerrige prøver på at kigge ind bag kulisserne for at se sagen selv inde fra.

Et generelt svar på ovennævnte spфrgsmål kan næppe gives, hverken nu eller senere. Men enhver sønderjyde ved, at dansk og tysk dengang ingenlunde kun kunne tegnes ved sort eller hvidt; men at der var brug for talrige grå nuancer, hvor farverne ligefrem flød over $i$ hinanden, og at der desuden var en brøk, en rest tilbage, som var farveløs. Alt det ses ikke af valgtallene, der er ingen udflydende konturer, kun skarpe skel.

Et samlet kildemateriale til belysning af de næunte spørgsmål mangler desværre helt, og vi er allerede nu disse begivenheder og personer så langt på afstand og så fjern i tid, at det heller ikke lader sig konstruere fra sogn til sogn. Men et sådant materiale må uden trivl have eksisteret engang. Den danske vælgerforenings tillidsmænd ude $i$ sognene har $i$ sin tid hver for sig udarbejdet en slags national mandtalsliste over samtlige valgere $i$ hvert sogn; men dette vigtige og interessante materiale synes desværre ikke bevaret. Kun rent undtagelsesvis kan man måske her eller der blandt de gamle nationale tillidsmiends papirer finde sådanne fortegnelser. De kan i så fald give eftertiden værdifulde fingerpeg til besvarelse af de ovenfor omtalte spørgsmål.

Når jeg i det følgende kan fremlægge et sådant "nationalt kataster « fra en enkelt egn af Nordslesvig, skyldes det, at min fader, gdr. og dbm. Bertram Paulsen i Østerløgum, har gemt det af ham og svogeren, gdr. og dbm. Hans Friis, Kopholt, i 1908 udarbejdede nationale register for $\emptyset$ sterløgum sogn (med undtagelse af Gjenner og Andholm kommuner). Sk $\phi$ nt det $i$ år er 50 år siden, det blev udarbejdet, har jeg dog kendt så at sige hver af de navnte personer og mener også, at jeg med bestemthed kan udtale mig om den enkeltes sindelag og indstilling til de nationale spørgsmål. Dette sidste var nemlig dengang det altdominerende ved omtale og vurdering af personer, i hvert fald hos dem for hvem den nationale kamp var blevet en livssag. 
Hans Frtis, Kopsholdt

(1853-1937).

Væalgerforeningens tillids-

mand $i$ valgdistriktets vestlige del.

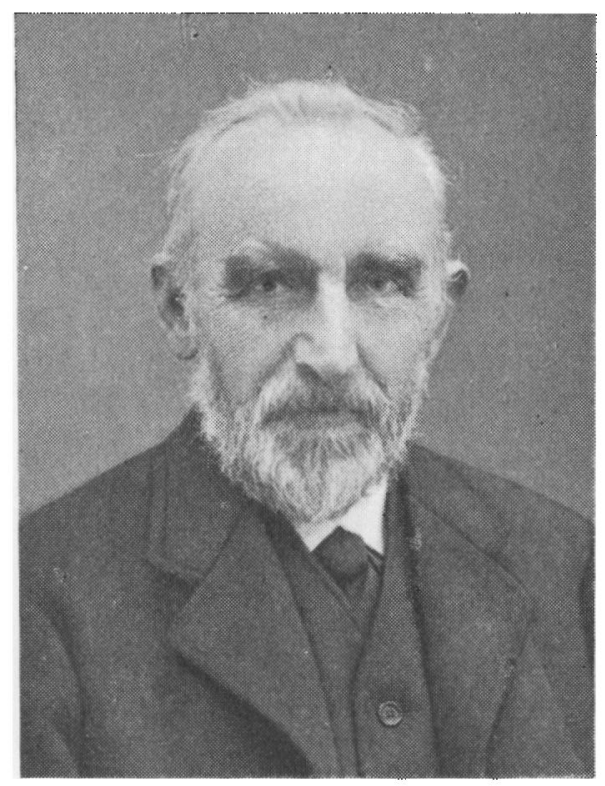

Ved at blade disse lister igennem og se de enkelte navne stiger en srunden tid og dens mennesker frem for ens blik. Så at sige hvert navn har været omtalt i mit hjem og dets nærmeste kreds. Historier om personer og om tildragelser ved valgene er blevet fortalt. Ofte var de muntre og blev gengivet med lune, f. eks. når en $\gg$ bestilingsmand « sn $\varnothing d$ tyskerne og undlod at afgive sin stemme, sk $\phi$ nt den regnedes til de sikre. Men der kunne også falde bitre bemærkninger, når en danskorienteret eller dansksindet stemte tysk eller blev hjemme, »ikke gjorde sin pligt « som det hed. Alle blev vurderet efter sindelaget, og om de mødte frem ved valgene. Dette var alle tings rette mål. Når vi $k \phi r t e ~ » t i l ~ s t a j s \ll$ - over Damgaard, Lunderupmark, Rødekro og Brunde - blev man som barn belært om, hvem der boede $i$ de forskellige gårde og huse, og om vedkommende mand var dansk eller tysk - eller noget tredie. Dette, at være »blakket «, var næsten det værste af alt. Det fik man i hvert fald indtryk af. Ingen er nemlig så udpræget national som den vågne del af befolkningen $i$ et grænsecområde. Der må kampen tages op - for dansk eller tysk - dag 


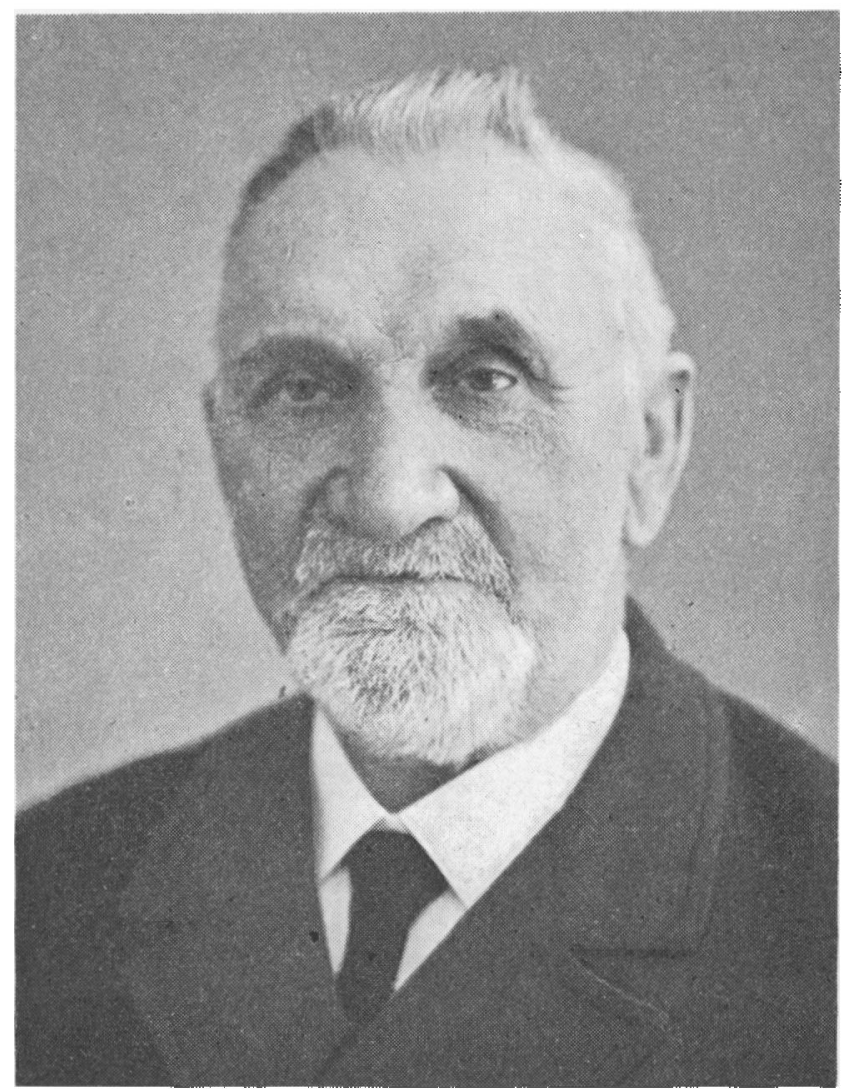

Bertram Paulsen (1867-1950), Ø. Løgum.

Velgerforeningens tillidsmand i valydistriktets ostlige del.

for dag. I brydningsfeltet mærker man på kroppen sammenstødene mellem to nationer.

I det f $\emptyset r s t e$ hus, vi kom forbi, boede Lorenz Nissen, pensioneret ledvogter, eller »bommand «, som det dengang hed. Han var dansk og stemte dansk. Men da han endnu var i tjenesten, havde han engang måttet begive sig til valglokalet for at stemme tysk. Hidtil havde han altid holdt sig hjemme, men under pres og trusler om at blive forflyttet til Holsten, hvis han ikke mødte til valg, måtte han så love at afgive sin stemme. Valgdagen oprandt, og Nissen 


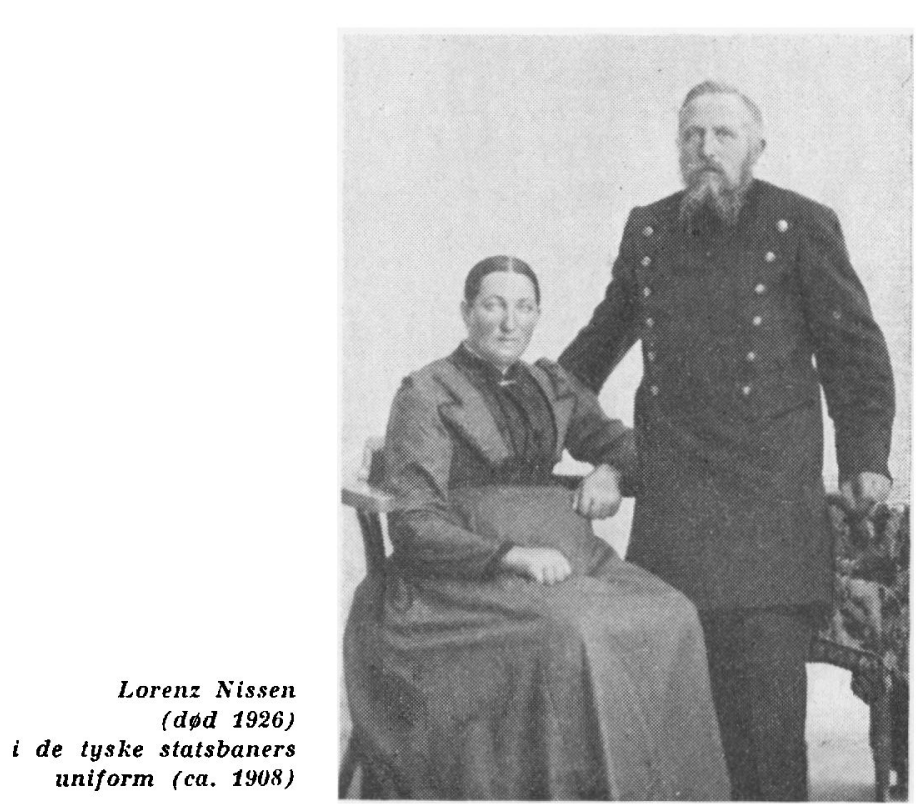

begav sig på vej. Da han kom, var valglokalet imidlertid lukket, og hverken amtsforstander eller valguestyrelse var modt endnu. Men krodøren var åben, og indenfor blev der snart liv og en glad dag, thi valgdagen var en festdag dengang. Af og til kom der en stafet for at purre vælgerne ud, og da den tyske hen pá eftermiddagen kom til Nissen, som sad $i$ et muntert lass, erklærede han kategorisk, at »da det passede mig, passede det ikke jer, og nu passer det ikke mig. « Og så stemte hele selskabet i med:

Vi er kun få, men det er er det samme, vi er en gren af den danske stamme.

Bagefter måtte han undskylde sig med, at da han var kommet for tidligt til valglokalet og dârlig kunne tåle kulden ved at stå udenfor og vente, var han gået ned $i$ kroen »for at få lidt at varme sig på«, og der havde han desværre fâet for mange »punser«. I 1903 måtte han så bekvemme sig til at stemme tysk, men siden - efter sin pensionering - stemte han hver gang dansk. Og således kunne min fader fortælle videre om personer og slægter, helt ind til Kolstrup. 


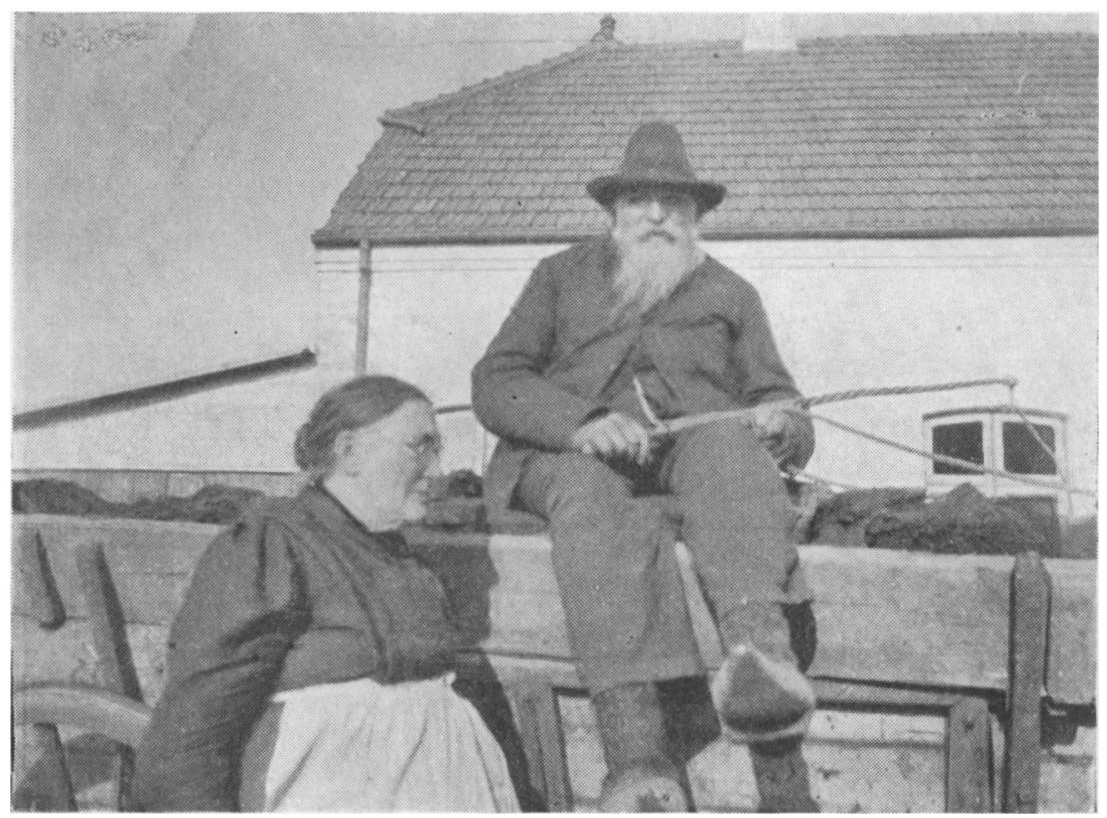

Lorenz Nissen som gammel. Billedet afspejler den gennemforte nфjsomhed, som prægede dette slagtled.

Nảr $\emptyset j e t$ nu så læenge efter fanger disse navne, og deres bærere træder frem $i$ erindringen, kan man ikke uden videre anbringe dem under de gængse betegnelser: danske, tyske, blakkede. Jeg vil tro, at kun et mindretal passer ind $i$ disse skarpt adskilte afdelinger. Blandt dem var udpræget nationale, ja ligefrem supernationale folk, mennesker, hvis nationalpolitiske opfattelse domineredes af en så ensporet problemstilling, at de tabte de store proportioner af syne. Også om det kunne der fortælles adskillige morsomme trak.

Den tyske del af valgerne var en meget broget skare. Der var først en del preussisk påhæng og rigstyske elementer, gendarm, stationsforstander, tjenestemænd ved statsbaner og postvæsen. endvidere nogle indvandrede håndværkere, som havde etableret sig. Enkelte af disse sidste var ikke ivrige efter at blive indblandet i nationalpolitiske stridigheder, da de var fødte ham- 
borgere og derfor på forhånd ret uinteresseret $i$ den nationale kamp, tilmed havde de kunder i begge lejre. Det kneb i hvert fald for tyskerne at få dem til at møde op ved valgene. Så var der hjemmetyskernes ret store skare, b $\varnothing$ nder med dybe r $\varnothing d$ der i hjemstavn og jord. Tyske $i$ ordets egentlige forstand var de ikke. Tysksindede slesvigere, med eftertryk på sidste ord, var snarere den rette betegnelse. Det ældre slægtled havde varet slesvigholstenere, deres forfædre igen hertugelig-gottorpske bønder. Erindringen om den gottorpske tid ( $f \varnothing r$ 1721) holdt sig længe levende og tegnede et lyst billede af forholdene dengang. Min oldefader, P. Kier, sognepræst i $\emptyset$ sterløgum 1802-34, var barnefødt i Hovslund og ved at fortælle en del herom. Da han var en kyndig historiker og kendte sit sogn, har hans ord vagt: ${ }^{1}$ )

»De gamle — dvs. folk født før 1721 - hang ved deres gamle Fyrstehus og vidste at fortalle, at man dengang levede vel og kun havde ringe Byrder og Skatter, og derfor var man utilfreds med den nye Herreveksel.« Den slesvig-holstenske tanke fæengede derfor $\mathrm{i}$ deres efterkommeres sind, og forestillingen om en egen hertug over det gamle hertugd $\varnothing$ mme Slesvig $\mathbf{i}$ forbindelse med Holsten var i disse kredse en kær tanke. ${ }^{2}$ ) Det stod dem vel næppe helt klart, hvad det egentlig drejede sig om, thi da en mand $i$ Hovslund i 1864 blev spurgt om, hvad de egentlig ville have under preusserne, svarede han: „Vi vil ha vor frihed og ret.e Men hvad det var, kunne han ikke gøre rede for, men måtte henvise spørgeren til gammel Per Nissen i Hjolderup.

Den gamle særslesvigske følelse er her sikkert nok oprindelsen til den senere tyskhed. Men ordet tyskhed bør dog kun nævnes med modifikationer. Og derfor kneb det for en og anden tyskorienteret eller tysksindet slesviger at forsvare v. Köllers metoder eller følge en dr. Hahn. Ikke Die Nordmark, men Slesvig var hjemstavn og bostavn, og dette begreb knyttede mange bånd til naboer og venner $i$ den anden lejr. Dansk var selvf $\varnothing$ lgelig omgangssproget og for resten også det hellige sprog, den danske guds-

1) Han har skrevet sognets historie, bl. a. Østerlygum Menigheds Annaler i 10 bind.

2) Jfr. min bog S $\phi$ nderjydske Slægter bind I. Østerløgum (1942) p. $273-77$ og nr. $26 \mathrm{~A}, 26 \mathrm{~B}, 27 \mathrm{~A}, 27 \mathrm{~B}, 28,30 \mathrm{~B}$. 
tjeneste med danske salmer og dansk prædiken af deres tysksindede sognepræst var den ideelle gudstjeneste. Så var der tyskorienterede slesvigere, folk uden megen politisk interesse, men imponeret af Tysklands storhed og magt og glade for den tyske landbrugspolitik. Soldatertiden havde en meget stor plads i deres erindringsverden, og en samtale med dem endte altid $i$ minderne om den store tid i fjerne tyske garnisonsbyer. Det er den slags »hjemmetyskere«, Jens Jessen har haft i tankerne, når han i sin tale i Stenskro i 1901 udtalte: $\gg$ De h $\phi$ rer til vort Folk, og der er altid Mulighed for, at de kan lære at indse det selv. Vor D $\phi \mathbf{r}$ maa altid staa paa Klem, naar de med god Vilje vil ty ind til os, deres Frænder, hvor de rettelig hører hjemme. Vi må ikke glemme at sætte Lys i Vinduet! «

Også en ikke ubetydelig flok tjenestemænd - eller »bestillingsmænd «, som det hed $\mathbf{i}$ datidens sprogbrug - hører med i billedet. Nord- og sydslesvigere, tysksindede og dansksindede, politisk indifferente, en enkelt socialist, alt i broget blanding. Bortset fra de få, som virkelig var dansk- eller tysksindede, kunne denne gruppe vel svinge til hvad side, det skulle være, når en valgdag oprandt, hvor valget stod frit mellem Danmark og Tyskland. Men alle stemte de tysk i 1903, 1908 og 1912. Også den dansksindede var nødt til at stemme tysk. Brød og hjem stod på spil. Folk i en betrygget økonomisk tilværelse forstod ikke altid dette.

Det romerske ord: ubi bene, ibi patria havde også sine tilhængere i Nordslesvig. Det var folk, som f $\not$ rst og fremmest anlagde rent $\emptyset$ konomiske synspunkter, materialister af reneste vand, som fandt det fordelagtigt at være under Tyskland. Endelig havde hvert sogn $i$ de tider en eller anden, hvem flasken eller livets møje og arbejdets slid eller alt $i$ forening havde knækket. Sløve og uinteresserede sad de i deres hytter og lod livet passere forbi. Et sådant navn optræder også af og til i den tyske rubrik. »Tysk « var således ret ubestemmeligt, og de tyske valgere var en broget skare.

Det samme må siges om de såkaldte »blakkede«. Kun de færreste af dem var vel egentlig "blakkede«, dvs. folk, som bar kappen på begge skuldre eller var forsigtigpetere, som af hensyn til 
En hedeparcellist, som stemte forste gang $i 1912$ (d.), sk申nt han var født i 1856. Bag hans navn stod $i$ mange ir pd valgerforeningens valgliste et ?. Rent menneskeligt en hedersmand fra top til to (død 19.41)

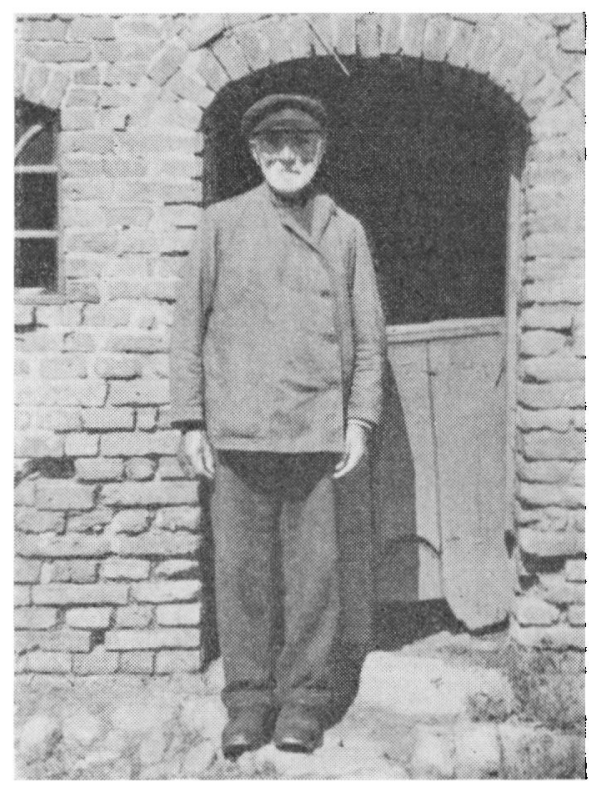

dit eller dat eller Per og Poul helt undlod at stemme. Men der var også en del folk, som ikke fortjente denne nedsættende betegnelse.

Man står her overfor et $i$ vide kredse skjult og upåagtet befolkningsanslag, som sjæleligt h $\phi$ rer hjemme i den snævre hjemstavn og i $\varnothing$ vrigt sympatiserer med begge politiske lejre --. eller med ingen. Talen om $\gg$ Weiströmigkeit « $i$ det slesvigske folkesind dækker ikke her, thi den forudsætter en kulturel indlevethed i begge kulturkredse, som ikke er tilstede. Men det må erkendes, at menneskeligt var denne folkedel $i$ enhver henseende fuldt så værdifuld som vi, der aldrig har beh $\phi$ vet at vælge. Ofte drejer det sig om særprægede, hjemmegroede mennesker, som levede $i$ deres egen verden, og hvem den nationale kamp var en uvedkommende affære. Ved at tænke på en af dem, en hedeparcellist, som i en sjælden grad havde levet sig sammen med naturen og hjemstavnens liv og fortid og skik, mindes man Th. Storms digt Abseits, hvor just sådan en hedehusmand midt under det politiske bulder og kampgnyet i 1848 læner sig over sin hyttes halvd $\phi$ r behaglich blintzelnd nach den Bienen, og om hvem det betegnende siges: 
Kein Klang der aufgeregten Zeit

drang noch in diese Einsamkeit.

Sådanne mennesker levede endnu her og der i stille egne op under 1914. Eller en og anden tog apostelordet: $\gg$ Vær $\phi$ vrigheden underdanig « bogstaveligt og betragtede derfor den standende kamp som ulydighed og menneskelig opsætsighed mod Guds klare bud. Det var ikke så lige folk, som tilhørte Indre Mission, men grublere og indadvendte mennesker. Kun 3 af vælgerne betegnes som tilhængere af I. M., alle dansksindede, de 2 stemte altid, den tredie »ikke sidst «. Der er ingen grund til at tro, at Den indre Missions venner her ville frig $\phi r e$ sig for sine folkelige pligter, men at de snarere har indset, at man for kristendommens skyld måtte være og blive sit folk og sit sprog tro.

En vis social spænding er vel uundgåelig, også $i$ et landsogn med nogenlunde samme kår for de fleste; men denne spænding var ikke så mærkbar, at den kunne danne baggrund for en socialistisk agitation, som satte ind i Nordslesvig i slutningen af århundredet. Selv om det danske »Social-Demokraten « spredtes over landsdelen ind under valg, og uagtet Pio allerede i 1877 havde opfordret de nordslesvigske arbejdere til at $\gg$ opgive ethvert Maskepi med Storborgerne. Slut Jer til det tyske socialistiske Parti. Vil I jeres Vel, saa slut Jer til jeres Kammerater, med hvem I har Fællesskab i Lidelse og Haab, « forblev sognet stort set uberørt af hele denne agitation. Skrædder Mahlke - »den sande Folkets Mand, Heinrich Mahlke«, som han kaldes i et opråb 1893 - fik kun 1 stemme i 1903, og Michelsen ligeledes kun 1 stemme i 1907. I 1912 steg de socialistiske stemmer til 4, de to blev af givet af rigstyske landbrugsarbejdere, som var kommet herop i mellemtiden, 1 stemme må formodentlig tilskrives en jernbanearbejder og den sidste en tilflyttet husmand. Selve den bosiddende del af befolkningen var således fuldkommen uberørt af bevægelsen $\mathbf{f} \phi \mathbf{r} 1914$.

De danske stemmer var mere ensartede. Det var frem for alt frivilligt mandskab. Frie mænd fra ende til anden. Og dog var der også her afvigelser og forskel. Enhver åndelig bevægelse har en flok, som med sjael og hu går ind for sagen, og som altid er 
rede til at ofre tid og penge, ja sig selv, om det bliver krævet. Disse mænd udgjorde kærnen i den danske lejr. De var rygraden i bevægelsen. \$Tro til Døden« står der med rette på Jens Jessens. gravsten, men adskillige andre, navnløse hverdagsmennesker, brændende $i$ ånden for den samme sag, lige så trofaste på deres post, fortjener de samme ord. Sagen kaldte altid ad dem. Modloshed i rækkerne måtte bekæmpes, de forknytte strammes op, de ligegyldige purres ud. Iveren og aktiviteten var uden tvivl st $\varnothing$ rst og stærkest blandt danskhedens tillidsmænd, og den viser, livilken dynamisk kraft der ligger i grænseatmosfæren. Uden disse navnl $\emptyset$ se tillidsmænd ville mellemslesvigske tilstande have rådet $\mathrm{i}$ store dele af Nordslesvig i 1914. Thi mange af de danske, måske flertallet, hørte — i hvert fald i Øster Løgum sogn — til de passive og måtte ustandselig holdes til ilden. De meldte sig ikke af sig selv som medlemmer af de nationale foreninger, men måtte nødes til det. Det var heller ikke uden videre givet, at de alle mødte frem ved valgene, mange gjorde det selvfølgelig, men andre måtte hentes ud. Deres danskhed bestod mere i en negativ afvisning af alt tysk end $i$ en positiv indlevethed $i$ og bekendelse til det danske. Dansksindede eller danskorienterede slesvigere er er vel den rette betegnelse for mange af disse valgere. De skede så vist ikke at kysse riset, men havde tyskerne anvendt andre midler $i$ deres bestræbelser for at vinde slesvigerne, havde de taget hensyn til fribårne mænds selvfølgelige ret til at synge, hvad de vilde, til at samles, hvor de vilde, til at tale og laese, hvad sprog de vilde, er det sandsynligt, at denne gruppe af valgere langsomt og umærkeligt var blevet loyale og tyskorienterede slesvigere. »I skal lære at nikke og bukke og sige Ja og Amen til alt, lıvad Magthaverne og deres Tilhængere siger og mener ... Det skal vise sig, om Udvisningerne, Tjenestedrengekrigen, Forhindring af danske M $\phi$ der, den $\emptyset$ konomiske Krig og alle de andre lignende Midler har været rigtig kærkomne hos Nordslesvigerne, om Tvangsregimet har vundet Befolkningens Yndest. Den faar Lov at vælge, om den vil lade sig kvæle eller slaa ihjel. Strikken eller Kniven? Befolkningen maa jo selv vide, om den vil gaa med vore Modstandere.\& Det var Jessens ord før valget i 1902 . Og de blev forstået helt ud i yderkredsen af danske vælgere. 
Som bekendt havde H. P. Hanssen og Jens Jessen forskelligt syn på de nationale opgaver i grænselandet. Mens den første sã det som en væsentlig opgave, at sønderjyderne kom under åndelig påvirkning nordfra - f. eks. gennem højskolen - for derved at gå op i det fælles danske, $\varnothing$ nskede Jessen frem for alt at hævde den slesvigske selvstændighed til de yderste konsekvenser; det såkaldte »folkelige « ville af sig selv vokse ud af folkets sande natur og sind. Betragter man nu vælgerne ud fra disse synspunkter, kan der ikke herske tvivl om, at det var Jessen, som kaldte den slumrende danskhed til live. Hvad der kom nordfra var ingenlunde altid og overalt højt $i$ kurs hos den jævne mand. Jessens tale derimod gav genlyd i mange sind og rejste en valgerskare, som ellers næppe var kommet på benene. Han har frem for nogen anden lagt den faste grobund for danskhed $i$ kritiske år.

Vælgerskaren lod sig altså ikke uden videre presse ind $\mathrm{i}$ de to kategorier. Men den danske bevægelse måtte $i$ sin daglige agitation og under kampen betjene sig af dem, skønt man ikke kunne være blind for, at der var betydelige nuancer. Ydre omstændigheder i samspil med individuelle anlæg, eller nedarvede synspunkter, eller slet og ret rent materialistiske bevæggrunde og meget andet kunne spille ind og skabe slørede konturer og ligefrem glidende standpunkter.

Det f $\not$ lgende materiale, som nu overgives offentligheden, tegner et billede af den nationale hverdag i tiden umiddelbart f $\phi r$ verdenskrigen 1914. Vel drejer det sig kun om et lille udsnit af vor befolkning, men alligevel kan det gælde for store dele af Nordslesvig udenfor Haderslev amt. Den, som med bekymring fulgte udviklingen, kunne her hente yderligere grunde til bestyrkelse af sin pessimisme. Men også optimisten kunne finde et og andet, som frydede ham. Begge havde dog sikkert den overbevisning, at skulle Nordslesvig engang forenes med Danmark, måtte det ske inden alt for længe.

Den nationale mandtalsliste omfatter alle vælgere i 1908 (det preussiske landdagsvalg). Ved mundtligt valg valgte hvert distrikts vælgere 3 - 4 valgmænd, som siden valgte landdagsmanden. Vælgerne er inddelt $i$ tre valgklasser, de $h ø j s t$, mindre og 
lavest beskattede, således at der på hver valgklasse faldt en trediedel af det samlede skattebeløb, som skulle udredes af samtlige vælgere $i$ distriktet. Hver af de 3 klasser valgte en trediedel af valgmændene. Skulle der vælges 3 eller 6 valgmænd, faldt altsả lige mange på hver klasse. I det omhandlede distrikt var der 14 vælgere i I. klasse, 36 i II. og 199 i III. klasse. Da valget var mundtligt, kunne stemmerne og stemmeafgivningen n $\varnothing$ je kontrolleres. Ved rigsdagsvalget derimod, som var hemmeligt og uden klasseinddeling, måtte der regnes med en fejlmargin, som dog viser sig at være forbavsende lille. I et landsogn, hvor alle kendte alle, var der kun få eksempler på, at vælgerne stemte anderledes end formodet. Men hvem disse vælgere var, stod hen i det uvisse. Da alle vælgere er opf $\varnothing \mathbf{r t}$ på listen, har man altså også en fortegnelse over de talrige passive vælgere, som enten betegnes ved d. (dansk), t. (tysk) eller ved $d$ ?, $t$ ? ikke tysk, nærmest tysk, vistnok dansk, eller simpelthen ved et spørgsmålstegn, fordi man ikke kunne komme nærmere end til dette ubestemmelige og uberegnelige tegn. Denne gruppe af vælgere er ikke lille, men ved rigsdagsvalget i 1912 skete et kraftigt indhug i rækkerne, og det viste sig, - hvad ingen med sikkerhed kunne vide - at disse vælgere overvejende stemte dansk. Bag dette glædelige resultat lå et ihærdigt og utrætteligt arbejde fra tillidsmændenes side, som nu bar sin synlige frugt ved det sidste tyske rigsdagsvalg.

Foruden den enkelte vælgers navn og stilling, bopæl og alder, er hans samlede skattebel $\phi b$ og sindelag anf $\phi \mathbf{r t}$, og om han m $\varnothing \mathrm{der}$ til valg. Så at sige alle vælgere er fødte sønderjyder, hovedsagelig nordslesvigere, ja de fleste er vel født i selve sognet. Der kan kun noteres enkelte rigstyske, som alle var tjenestemænd ved statsbanerne eller postvæsenet, eller indvandrede arbejdere og håndværkere. Så vidt jeg kan se, er kun een vælger fø̆dt $\mathbf{i}$ Danmark, og denne ene rigsdansker er en »Jyllandstysker «. På listen optræder han som pensioneret jernbanearbejder; han var den eneste $i$ sognet, som mødte op i skolen på kejserens f $\emptyset$ dselsdag for at overvære $h \varnothing j$ tideligheden der $\mathrm{i}$ dagens anledning. De tyske valgere undgik sligt, men den nationale renegat fandt det passende.

Kampen stod i 1908 først og fremmest om I. klasse. Hidtil 
havde danskerne haft flertallet i alle 3 klasser, men i 1907 havde myndighederne overf $\phi r t$ en del af distriktets vælgere (Andholm kommune) til Bodum valgdistrikt i L $\phi j t$ sogn. Sligt kaldtes dengang valggeometri, og derved mistede I. klasse 2 danske vælgere. Nu stod 7 danske over for 7 tyske stemmer. $O g$ tilmed var der et svagt led $i$ den danske kæde, idet en af vælgerne var bestillingsmand (restaurat $\varnothing \mathbf{r}$ og postekspedit $\varnothing r$ ), men alligevel stemte dansk ved rigsdagsvalgene. Under presseri og forestillinger formảede tyskerne ham nu til at stemme tysk, og dermed var flertallet $i$ I. klasse tabt.

I II. klasse havde danskerne et sikkert flertal, og i III. klasse var overvejende dansksindede vælgere, men her var de mange ubestemmelige og det store tal på passive folk. Af de 249 vælgere kunne danskerne regne med at få 117 sikre stemmer $\left(\begin{array}{ll}4 & c_{c}^{\prime}\end{array}\right)$, tyskerne med $78(31 \%)$, mens resten var passive vælgere (22\%), dvs. en del var danske og blandt dem adskillige, som for havde stemt dansk, færre af dem var tysksindede eller tyskorienterede folk, og ikke få var uberegnelige vælgere, idet de aldrig mødte til valg.

Inddeler man vælgerne efter deres stand og stilling, får man følgende resultat:

\begin{tabular}{|c|c|c|c|c|c|c|c|c|c|c|c|c|}
\hline & 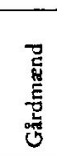 & 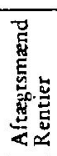 & 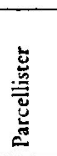 & 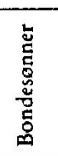 & 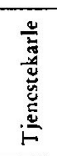 & 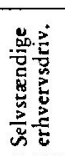 & 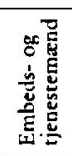 & 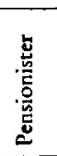 & 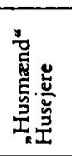 & 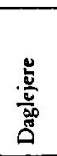 & a & $\underline{\underline{u}}$ \\
\hline & 5 & 1 & - & - & - & - & - & - & - & --- & - & 6 \\
\hline I. kl. t. & 6 & - & - & - & - & - & 2 & - & - & - & - & 8 \\
\hline & - & - & - & - & - & - & - & - & - & - & - & 0 \\
\hline & 18 & 1 & - & - & - & - & - & 1 & - & - & - & 20 \\
\hline II. kl. t. & 10 & - & - & - & - & 1 & - & - & - & - & - & 11 \\
\hline & 3 & - & - & - & - & 2 & - & - & - & - & - & $\bar{\alpha}$ \\
\hline & 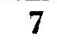 & 8 & 28 & $\mathbf{5}$ & 9 & 20 & - & 1 & 10 & 3 & - & 91 \\
\hline I. kl. t. & 4 & 2 & 8 & - & 2 & 6 & 25 & 5 & 4 & 3 & - & 59 \\
\hline$\div$ & 2 & 8 & 18 & - & 1 & 3 & 2 & 2 & 5 & 6 & 2 & 19 \\
\hline ialt & $5 \overline{5}$ & 20 & 54 & 5 & 12 & 32 & 29 & 9 & 19 & 12 & 2 & 249 \\
\hline d. & 31 & 10 & 28 & 5 & 9 & 20 & - & 2 & 10 & 3 & - & 117 \\
\hline $\mathrm{t}$. & 20 & 2 & 8 & & 2 & 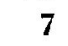 & 27 & 5 & 4 & 3 & - & 78 \\
\hline$\div$ & 5 & 8 & 18 & - & 1 & 5 & 2 & 2 & 5 & b & 2 & 54 \\
\hline
\end{tabular}


Set fra et dansk synspunkt klarede gruppen »selvstændige erhvervsdrivende sig bedst. 62,5 \% af dens valgere stemte dansk. 21,9 0 ' tysk, mens kun 15,6\% undlod at stemme.

I en tid, hvor kampen om jorden var i fuld gang, og hror iyskerne havde oprettet statsfæsteejendomme — på listen kaldes disse vælgere »Rentegodsbesiddere — spurgte man først og fremmest om, hvem der ejede jorden. Svaret er, at her i distriktet har $\mathbf{5 4 , 5} \%$ af bønderne stemt dansk. Tæller man parcellisterne med, hvilket er rimeligt, da de repræsenterede en betydelig del af de jordejende, er tallene f $\varnothing$ lgende:

Danske 53,2 \%, tyske 25,7\%, ? 21,5\%.

Der er altså kun tale om et knebent flertal, som ved små forskydninger let kunne reduceres til et mindretal. Grupperne aftægtsmænd, bondes $\varnothing n n e r$ og tjenestekarle bør ses i sammenhæng hermed, da de første er afgåede, de sidste vordende gårdmænd og parcellister. Af aftægtsmændene og lign. stemte $50 \%$ dansk, $10 \%$ tysk, $40 \%$ stemte ikke. Tallene for de to andre grupper tilsammen er henholdsvis $82,4 \%$ danske, $11,8 \%$ tyske, $5,8 \%$; undlod at stemme. Den kommende generation var altså $\mathbf{i}$ overvejende grad danskorienteret. Tallene er ret tilfældige, da de kun repræsenterer 17 af 249 stemmeberettigede, men alligevel er de et fingerpeg.

En tredie hovedgruppe er »Embeds- og Bestillingsmand «. Denne gruppe havde tyskerne kontrol over, og her havde de deres sikre stemmer. 93,1 \% af disse valgere stemte da også tysk, ingen dansk og kun 2 af vælgerne undlod at stemme; det drejer sig om en tyskfødt tjenestemand, som formodentlig har været socialdemokrat og ikke har stemt ved landdagsvalget, og en arbejder, som før har stemt dansk, men nu var »Amtstjener «, dvs. amtsforstanderens bud $\mathrm{m}$. $\mathrm{m}$. Han har ikke villet stemme tysk, og hans arbejdsgiver må have tilladt ham at blive hjemme.

Endelig er der arbejderne (på listen »Husmænd «, dvs. arbejdere med eget hus og en ubetydelig jordlod, husejere, d. e. arbejdere med eget hus og arbejdere og daglejere, de sidste er lejehusfolki. Hertil hører også de 2 vælgere, hvis erhverv ikke er nævnt. Næesten $40 \%$ af denne gruppe er passive vælgere. Danskerne kunne regne med at få $39-40 \%$ af stemmerne. 
En ganmel pessimist og en ung optimist sad og betragtede disse tal. „Strømmen fortærer mere og mere af vor strand - begyndte den gamle med at sige - og trods alle vore anstrengelser kommer den os nærmere og nærmere. I 1867 havde vore modstandere kun 14,4 af de stemmeberettigedes stemmer,") i 1903 havde de dobbelt så mange, ${ }^{4}$ ) og næsten en tredie del af vælgerne blev hjemme. Indtil nu har vi ved hvert landdagsvalg kun valgt danske valgmænd, nu er I. klasse tabt, og tyskerne æder sig ind på II. klasse, så den også kommer i farezonen. Ja, ikke engang III. klasse er sikker mere. I det фjeblik de uberegnelige og ubestemmelige og passive vælgere slår over på tysk side, er også den tabt. Selv jorden svinder bort under vore f $\varnothing$ dder, endnu er hovedparten i dansk eje, men hvor længe? For mig at se begynder vore tal at smuldre. 9 af vore, som ellers altid har stemt dansk, blev hjemme ved sidste valg, og 10 af dem kan vi aldrig få frem. Ved over 20 navne har vi måttet sætte et spørgsmålstegn, og skønt ingen af dem er egentlig tyske folk, kan de vel alligevel svinge $i$ den gale retning. Tyskerne har desuden en ikke ringe reserve blandt dem af deres vælgere, som ikke stemte sidst. 9 af dem er tysksindede og̊ 3 vistnok også. Og er de 91 danske stemmer i III. klasse sikre? I de yngste aldersklasser har de tyske stemmer en bedre placering end vore. ${ }^{5}$ )

Der er desuden ogrså et mandefald at notere. I Rovbjerg blev 6 danske vælgere hjemme denne gang, og en dansksindet i II. klasse stemte tysk. En arbejder, som tidligere altid har stemt dansk, stemte nu tysk, fordi hans s $\varnothing$ nner er blevet banearbejdere. Vil fremtiden bringe flere af den slags overraskelser? Flertallet af vore stemmer er sikre nok, men ude i yderkredsen er en kant, som en sk $\phi$ nne dag kan skride. Strømmen er hård.

Er de tyske stemmer da sikre? indskyder optinisten. Tænk, hvis valget engang står mellem Danmark og Tyskland, og hele det preussiske påhæng er forsvundet, hvad mon der så bliver til-

3) 1867 hele sognet 247 d., 52 t., 60 stemte ikke.

4) 1903. Sognet uden Gjenner: 102 d., 67 t., 68 stemte ikke.

5) Af valgerne under 35 år stemte 18 d., 18 t., mens 7 blev hjemme. Disse stemmer repræsenterede $23 \%$ af de tyske, men kun $15.4 \%$ af de danske. 
bage af stemmerne fra bestillingsmændene? Der er adskillige dansksindede iblandt dem, i dag er de n $\phi$ dt til at stemme tysk; men når et aprilsvejr en skønne dag går hen over vort land, for-. svinder disse stemmer som sne for solen. Det samme kan siges. om adskillige andre tyske stemmer. Så er der alle de passive vælgere, her har vi en reserve, som må frem i dagens lys. Men det koster arbejde. Væk de dorske, styrk de svage. Hvis det lykkes, ser det anderledes ud i 1912.«

Oversigt over III. klasses passive vælgere:

ialt 49. 19 sstemte ikke sidst «, heraf stemte i 1912:

\begin{tabular}{c|l}
\hline heraf betegnes 9 som danske & 5 dansk, 1 socialistisk \\
4 tyske & 4 tysk \\
1 nærmest tysk & dansk \\
1 dansk? & dansk \\
4 ? & 1 dansk ?, 1 ?, (soc. ?).
\end{tabular}

30 »stemmer ikke."

\begin{tabular}{|c|c|c|}
\hline heraf & $\begin{array}{l}6 \text { danske } \\
2 \text { ikke tyske } \\
19 \text { ? } \\
4 \text { tyske } \\
1 \text { nærmest tysk } \\
1 \text { dansk? } \\
1 \text { fornylig preuss. } \\
\text { undersåt }\end{array}$ & $\begin{array}{l}4 \text { stemte d. i } 1912,2 \text { stemte ikke } \\
\text { stemte ikke } \\
4 \text { stemte dansk, } 15 \text { stemte ikke, } \\
1 \text { tysk?, } 3 \text { stemte ikke, } \\
\text { stemte ikke } \\
\text { stemte dansk } \\
\text { stemte dansk }\end{array}$ \\
\hline
\end{tabular}

Resultatet blev, at af disse 49 vælgere stemte 17 dansk, 5 tysk (heraf 1 socialistisk), mens 3 stemmer var usikre.

Stemmetallene $i$ distriktet 1903-12.

$\left.1903^{6}\right) \quad 102$ d. $(42,8 \%) \quad 69$ t. $(29,0 \%) 67$ stemte ikke $(28,2 \%)$

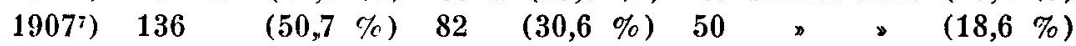

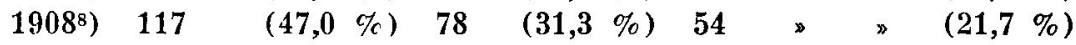

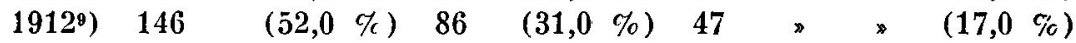

6) Mærkeligt nok stemmer de opgivne stemmetal i Haandbog for det nordsl. Sp $\varnothing$ rgsmaals Historie I (1938) p. 273 ikke med de stedlige oplysninger, som er fulgt $i$ ovenstående tal. Valglisten 1903 har følgende påtegning med $\mathrm{H}$. N. Callesens hånd: Andresen 102. Raab 47, Wolgast 20, Mahlke 1, Velde 1, ialt $69 \mathrm{t}$. stemmer.

$7,8,9)$ Se næste side. 
Mens de tyske stemmer stagnerer procentvis, er de danske gået ikke uvæsentlig frem. Befolkningstilvæksten har de danske stemmer optaget, og ligeledes er det lykkedes de danske at gøre betydelig indhug i de passive vælgeres tal. Alt det betød opmuntring i $\varnothing$ jeblikket og tillid til fremtiden; men alligevel var stillingen ikke uden farlige perspektiver, især når den tyske valggeometri blev yderligere udvidet. Det fremgår af følgende brev fra tillidsmanden til daværende redaktør Refslund Thomsen i Aabenraa. Det viser, hvor n $\phi j e$ man fulgte udviklingen med det kommende landdagsvalg i 1913 for $\emptyset j e$.

Østerløgum 9. April 1912.

Hr. Redakt $\varnothing \mathbf{r}$ Thomsen.

I f $\phi$ rste Klasse vil der ske en ikke ubetydelig Forandring til vor Fordel. N. N. ${ }^{10}$ ) (t.) har delt sin Gaard, en S $\phi n$ har faaet en Trediedel, desuden har han bygget for ca. 20.000, så han vil komme langt ned i Skat. N. N." ) havde før en Indtægt af $800 \mathrm{Mk}$. som Postmester, som Tyskerne har taget fra ham. Kanske han endnu kan blive i I. Klasse, men dengang stemte han tysk under Pres fra Postvæsnet. En god Bekendt af ham mener for sikkert, at han ikke vil stemme tysk. En anden (t.) har solgt det meste af sin Gaard til en Tysker, men ingen af dem kan komme i $I$. Klasse. Andreas Iversen i R. er d $\phi d$, og Enken sidder med Gaarden, saa den Skat vil jo ogsaa falde bort.

Hans Paulsen i H. (d.) vil derimod komme i I. Klasse, desværre vil der vistnok ogsaa komme en Tysker til, nemlig $N$. N. her-

7) Heller ikke valgtallene 1907 stemmer overens med de stedlige. Valglisten 1907 har følgende tilføjelse (med Bertram Paulsens hånd): P. Grau 136. Wommelsdorf 46, Dr. Duus 26, Pastor Nielsen 8, Grev Reventlow 1, Michelsen 1, ialt 82 tyske stemmer. "Pastor Nielsen * er identisk med Nic. C. Nielsen, ,Den sidste Slesviger $<$, da sognepræst i Tandslet, $f \varnothing \mathrm{r}$ i Sommersted. Han fik ved valget i 1907 ialt 52 stemmer (jfr. Sønderj. årbøger 1958, p. 40). I Østerløgnm har ingen af Den indre Missions venner stemt på ham. De 8 stemmer, som faldt på ham, synes ikke medregnet i de officielle tal, er de mon kasseret?

8) Tallene stammer fra den nationale mandtalsliste.

9) Haandbog I. p. 273146 d., 81 t., 4 soc., ialt 85 tyste stemmer.

10) Nr. 1 på listen.

11) Nr. 3. 
steds. Forgængeren (Nr. 39 paa Listen) havde hele Ejendommen til Gæld, hvorimod N. N. maaske har Penge paa Rente.

Det store Skattebel $\emptyset b$, der kommer ud af denne Klasse, skal jo erstattes fra II. Klasse, og de 2 f $\phi$ rste kan jo vist ikke klare det; men vi har danske helt ned til Nr. 22.

N. N.s ældste Søn har været forlovet i 1 Aar, og det kan jo ske, at han skal have Gaarden inden næste Valg; men saa maa han jo formaas til at pagte den, da der ellers gaar en Stemme tabt. De samme Udsigter er hos $\mathbf{N}$. N. i H. og N. N. i R., som begge er tyske. Man kan ikke sige noget for sikkert, men man kan ikke tro andet, end at vi med Lethed kan vinde I. Klasse. - Hvis Tyskerne derimod tager Rugbjerg fra og lægger den til Horsbyg, saa kan vi ikke klare os. Kanske Tyskerne saa vinder $i$ alle Klasser.

For flere Aar siden tog de Gjenner fra, sidste Gang Andholn, som gjorde, at de vandt i I. Klasse. Kan der nu ikke være Fare for, at de tager Rugbjerg fra?

\section{Venlig Hilsen}

Bertram Paulsen.

\begin{tabular}{|c|c|c|c|c|c|c|}
\hline $\begin{array}{l}\text { Navn } \\
\text { I. klasse. }\end{array}$ & Bopæl & Stand & $\begin{array}{l}\text { Al- } \\
\text { der }\end{array}$ & $\begin{array}{c}\text { Samlet } \\
\text { skatte- } \\
\left.\text { bel } \emptyset b^{12}\right)\end{array}$ & $\begin{array}{l}\text { Sinde- } \\
\text { lag }\end{array}$ & $\begin{array}{c}\text { Møder } \\
\text { han? }\end{array}$ \\
\hline 1. Nis M. Nissen & & & & & & \\
\hline Madsen & Hovslund & gdr. & 55 & 409,84 & tysk & ja \\
\hline 2. Hans Friis & Kopsholdt & gdr. & 55 & 299,25 & d. & ja \\
\hline 3. N. N. & & & & 189,52 & d. st. t. & ja \\
\hline 4. Peter Andrese & Hovsl. & gdr. og amt & orst. & 168,73 & t. & ja \\
\hline 5. Friedrichsen & $\emptyset$. I. & sognepræst & 55 & 168,40 & t. & ja \\
\hline 6. H. Lorentzen & Hovsl. & gdr. & 55 & 158,31 & d. & ja \\
\hline 7. Ebbe Juhl & do. & gdr. & 60 & 152,28 & d. & ja \\
\hline 8. Iver Jessen & Rovbj. & gdr. & 30 & 143,30 & d. & ja \\
\hline 9. Th. Schmidt & Hovsl. & gdr. & 30 & 132,54 & t. & ja \\
\hline 10. H. Thomsen & do. & gdr. & 45 & 129,72 & t. & ja \\
\hline 11. Kr. Bruhn & Jarup & gdr. & 40 & 127,31 & t. & ja \\
\hline 12. J. Ravn & ด. L. & rentier & 70 & 122,64 & d. & ja \\
\hline 13. Andr. Iversen & Rovbj. & gdr. & 30 & 119,15 & d. & ja \\
\hline 14. P. Hansen & do. & gdr. & 65 & 118,95 & t. & ja \\
\hline
\end{tabular}

12) Indkomstskat til staten, kommuneskat, Ergänzungssteuer, Gewerbesteuer. 


\section{Navn}

\begin{tabular}{|c|c|c|c|c|c|c|}
\hline 15. N. N. & Rovbj. & gdr. & 45 & 116,85 & d. & ja \\
\hline 16. 一 & do. & gdr. og k.forst. & & 112,94 & t. & ja \\
\hline 17. - & do. & gdr. & 30 & 110,79 & d. & ja \\
\hline 18. - & Hovsl. & gdr. & 30) & 110,57 & ikke tysk & nej \\
\hline 19. 一 & $\emptyset . \mathbf{L}$. & gdr. & 60 & 102,94 & d. & ja \\
\hline $20 . \quad-$ & $\emptyset . \mathbf{L}$. & gdr. & 65 & 94,13 & d. & ja \\
\hline 21. - & Rovbj. & gdr. & 65 & 92,49 & d. & ja \\
\hline 22. - & Rovbj. & gidr. & 40 & 89,24 & d. & ja \\
\hline 23. - & Hovsl. & godr. & 55 & 85,36 & t. & ja \\
\hline 24. - & $\emptyset . \mathbf{L}$. & gdr. & 55 & 83,65 & d. & ja \\
\hline 25. - & Jarup & rentegdsbsdr. 4 & 40 & 81,85 & t. & ja \\
\hline 26. - & Jarup & gdr. & 40 & 80,64 & d. & ja \\
\hline 27. - & $\emptyset . \mathrm{L}$. & gdr. & 60 & 74,88 & t. & ja \\
\hline 28. - & Hovsl. & rentegdsbsdr. 3 & 30 & 71,57 & t. & ja \\
\hline 29. - & Rovbj. & gdr. & 35 & 71,39 & d. & ja \\
\hline 30. - & Hovsl. & gdr. & 40 & 68,90 & t. & ja \\
\hline 31. - & Rovbj. & gdr. skovops. 5 & 55 & 68,84 & ikke tysk & stemte $t$. \\
\hline 32. - & Jarup & gdr. jernb.arb. & & 67,42 & ? & $?$ \\
\hline 33. - & Hovsl. & gdr. & 40 & 66,99 & d. & ja \\
\hline 34. - & $\emptyset . \mathbf{L}$. & gdr. & $5 \overline{5}$ & 66,72 & d. & ja \\
\hline 35. - & Hovsl. & købmand & 55 & 65,80 & d. & nej \\
\hline 36. - & Rovbj. & gdr. & & 63,31 & d. & nej \\
\hline 37. - & Hovsl. & & & 62,67 & d. & ja \\
\hline 38. - & $\emptyset . \mathrm{L}$. & gdr. & 30 & 59,40 & d. & ja \\
\hline 39. - & do. & stationsvart & 30 & 59,02 & t. & ja \\
\hline 40. -- & Jarup & gdr. & 45 & 56,78 & d. & ja \\
\hline 41. - & do. & gdr. & 65 & 56,15 & d. & ja \\
\hline 42. - & do. & gdr. & 70 & 55,88 & t. & ja \\
\hline 43. - & Rovbj. & rentier & 55 & 52,75 & d. & ja \\
\hline 44. - & Hovsl. & gdr. & 30 & 52,33 & t. & ja \\
\hline 45. -- & $\emptyset . \mathrm{L}$. & gdr. komm.fst.4 & 45 & 51,75 & t. & ja \\
\hline 46. - - & $\emptyset . \mathrm{L}$. & gdr. & 55 & 50,51 & ikke t. & nej \\
\hline 47. - & do. & pens. degn & 65 & 50,20 & d. & ja \\
\hline 48. - - & do. & gdr. & 55 & 49,71 & d. & ja \\
\hline 49. - & Rovbj. & gdr. & 55 & 47,18 & d. & ja \\
\hline 50. - & Jarup & gdr. & 55 & 45,80 & d. & ja \\
\hline \multicolumn{7}{|l|}{ III. Klasse. } \\
\hline 51. N. N. & $\emptyset . \mathrm{L}$. & gdr. & 60 & 45,58 & d. & ja \\
\hline 52. - & Hovsl. & forpagter & 30 & 45,20 & nærm.t. i & ikke sidst \\
\hline
\end{tabular}

\section{Samlet}

Al- skatte- Sinde- Møder der bel $\left.\phi b^{12}\right)$ lag han?

\section{II. klasse.}




\section{Navn}

$\begin{array}{ll}\text { 53. } & -- \\ 54 . & - \\ 55 . & - \\ 56 . & - \\ 57 . & - \\ 58 . & - \\ 59 . & - \\ 60 . & -- \\ 61 . & - \\ 62 . & - \\ 63 . & - \\ 64 . & -- \\ 65 . & - \\ 66 . & - \\ 67 . & - \\ 68 . & - \\ 69 . & - \\ 70 . & - \\ 71 . & - \\ 72 . & - \\ 73 . & - \\ 74 . & - \\ 75 . & - \\ 76 . & - \\ 77 . & - \\ 78 . & - \\ 79 . & - \\ 80 . & -- \\ 81 . & - \\ 82 . & - \\ 83 . & - \\ 84 . & - \\ 85 . & - \\ 86 . & - \\ 87 . & - \\ 88 . & - \\ 89 . & - \\ 90 . & - \\ 91 . & - \\ 92 . & - \\ & \\ 7 & \end{array}$

Samlet Al- skatteder bel $\phi b^{12}$ )

$35 \quad 43,73$

$35 \quad 41,56$

$55 \quad 40,58$

$75 \quad 39,66$

$40 \quad 39,24$

$40 \quad 37,18$

$40 \quad 37,10$

$35 \quad 37,00$

$45 \quad 34,09$

$40 \quad 33,63$

$45 \quad 33,59$

$35 \quad 33,40$

$35 \quad 32,00$

$65 \quad 31,77$

$40 \quad 31,53$

$35 \quad 31,00$

$40 \quad 31,00$

$\begin{array}{clll}\text { Hovsl. } & \text { k } \phi \mathrm{bm} . & \mathbf{5 0} & \mathbf{2 9 , 9 5} \\ \text { do. } & \text { skom.m. } & 40 & \mathbf{2 9 , 6 0}\end{array}$

$\begin{array}{clll}\text { Hovsl. } & \text { li } \phi \mathrm{bm} . & \mathbf{5 0} & \mathbf{2 9 , 9 5} \\ \text { do. } & \text { skom.m. } & \mathbf{4 0} & \mathbf{2 9 , 6 0}\end{array}$

Jarup parcell. $\quad 65 \quad 29,52$

$\begin{array}{llll}\text { do. } & \text { do. } & 60 & 29,51\end{array}$

ø. L. gdr. $\quad 45 \quad 29,00$

Rovbj. parcell. $\quad 30 \quad 28,75$

Rovbj. parcell. $25 \quad 28,35$

Hovsl. rentegodsb. $25 \quad 25,87$

Hovsl. bagerm. $30 \quad 25,67$

do. banearb. $50 \quad 25,39$

ø. L. tidl. k $\phi \mathrm{bm} . \quad 35 \quad 25,37$

do. parcell. $\quad 60 \quad 25,07$

Rovbj. do. $50 \quad 24,05$

Hovsl. stationsforst. $50 \quad 24,00$

do. parcell. $50 \quad 23,01$

do. do. $35 \quad 22,54$

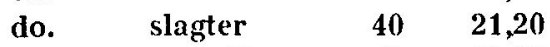

do. parcell. $40 \quad 20,65$

do. smed $35 \quad 20,60$

Rovbj. Parcell. $\quad 35 \quad 19,14$

Hovsl. snedker $35 \quad 19,00$

$\emptyset$ L. parcell. $\quad 50 \quad 18,29$

$\begin{array}{lll}\text { Hovsl. maler } & 40 & 18,20\end{array}$

\section{Sinde- M $\varnothing$ der \\ lag han?}

t. ja

t. ja

d. ja

d. ja

d. ja

t. nej

t. ja

t. ja

d. ja

d. ja

d. ja

t. ja

d. ja

d. nej

d. ja

l. ja

t. ja

d. ja

t. ikke sidst men ellers

d. ja

t. ja

t. ja

d. har ikke st.

d. ja stemt t.

d. ja

t. ja

d. ja

? nylig pr. u.

d. ikke sidst

t. ja

? nej

d. ja.

t. ja

d. ja

d. ja

? nej

t. ja

d. ja

t. ikke sidst 


\begin{tabular}{|c|c|c|c|c|c|c|c|}
\hline & Navn & Bopæl & Stand & $\begin{array}{l}\text { Al- } \\
\text { der }\end{array}$ & $\begin{array}{c}\text { Samlet } \\
\text { skatte- } \\
\left.\text { bel } \phi b^{12}\right)\end{array}$ & $\begin{array}{c}\text { Sinde- } \\
\text { lag }\end{array}$ & $\begin{array}{c}\text { Møder } \\
\text { han? }\end{array}$ \\
\hline 93. & - & do. & $\mathbf{k} \emptyset \mathbf{b m}$ & 40 & 18,20 & d. & ja \\
\hline 94. & 一 & do. & tømrer & 60 & 18,20 & t. & ikke sidst \\
\hline 95. & - & Jarup & pens. jernb.arb. & .70 & 18,20 & t. & ikke sidst \\
\hline 96. & - & do. & parcell. & 35 & 17,97 & d. & ja \\
\hline 97. & - & $\emptyset . \mathbf{L}$. & do. & 35 & 17,45 & t. & ja \\
\hline 98. & -- & do. & do. & 60 & 17,35 & t. & ja \\
\hline 99. & - & Rovbj. & snedker & 35 & 17,18 & d. & ja \\
\hline 100. & - & do. & smedem. & 35 & 17,13 & d. & ja \\
\hline 101 & - & $\emptyset$. L. & parcell. & 40 & 16,94 & $?$ & nylig pr. u. \\
\hline 102. & - & Hovsl. & do. & 55 & 16,92 & d. & ja \\
\hline 103. & - & $\emptyset . \mathbf{L}$. & do. & 35 & 16,70 & d. & ja \\
\hline 104. & - & Hovsl. & do. & 50 & 16,57 & d. & ja \\
\hline 105. & $-\cdot$. & $\emptyset . \mathrm{L}$. & do. & 65 & 16,35 & d. & ja \\
\hline 106. & - & Rovbj. & rentier & 65 & 16,00 & d. & ja \\
\hline 107. & - & Hovsl. & murer & 40 & 15,93 & t. & ja \\
\hline 108. & - & do. & bondes $\varnothing n$ & 28 & 16,00 & d. & ja \\
\hline 109. & -- & $\emptyset . \mathbf{L}$. & parcell. & 45 & 15,24 & $?$ & nej \\
\hline 110. & - & do. & do. & 50 & 15,24 & d. & ja \\
\hline 111. & - & $\emptyset . \mathbf{L}$. & pens. banearb. & 55 & 15,14 & d.? & ikke sidst \\
\hline 112. & - & do. & parcell. & 40 & 15,09 & d. & ja \\
\hline 113. & - & Hovsl. & dò. & 50 & 14,81 & d. & nej \\
\hline 114. & - & $\emptyset . \mathbf{L}$. & do. & 55 & 14,80 & d. & ja \\
\hline 115. & - & $\emptyset . \mathrm{L}$. & parcell. & 55 & 14,38 & d. & ja \\
\hline 116. & - & do. & do. & 65 & 14,25 & t. & ja \\
\hline 117. & - & Hovsl. & murer & 30 & 13,93 & d. & ja \\
\hline 118. & - & $\emptyset$. L. & parcell. & 60 & 13,86 & d. & ja \\
\hline 119. & - & Hovsl. & do. & 30 & 13,80 & $?$ & nej \\
\hline 120. & - & Rovbj. & do. & 45 & 12,98 & d. & ja \\
\hline 121. & 一 & $\emptyset . \mathbf{L}$. & do. & 35 & 12,81 & d. & ja \\
\hline 122. & 一 & Hovsl. & do. & 45 & 12,67 & t. & nej \\
\hline 123. & 一 & do. & do. & 45 & 12,62 & d. & ja \\
\hline 124. & -- & Rovbj. & do. & 35 & 12,30 & d. & ja \\
\hline 125. & 一 & Hovsl. & laerer & 35 & 12,00 & t. & ja \\
\hline 126. & - & Jarup & aftægtsm. & 55 & 12,00 & d. & ja \\
\hline 127. & - & do. & lærer & 25 & 12,00 & t. & ja \\
\hline 128. & - & & & $\mathbf{3 0}$ & 11,99 & d. & ikke sidst \\
\hline 129. & 一 & Rovbj. & parcell. & 40 & 11,95 & d. & ja \\
\hline 130. & 一 & Barlund & do. & 45 & 11,75 & d. & ja \\
\hline 131. & - & Rovbj. & pens. banearb. & .60 & 11,66 & d. & ja \\
\hline 132. & - & $\emptyset . \mathrm{L}$. & parc. skrædd. & 45 & 11,42 & d. & ja \\
\hline 133. & 一 & Hovsl. & parcell. & 65 & 11,42 & d. & ikke sidst \\
\hline
\end{tabular}




\section{Navn}

\begin{tabular}{|c|c|}
\hline $\begin{array}{l}134 . \\
135 .\end{array}$ & - \\
\hline 136. & - \\
\hline 137. & - \\
\hline 138. & -- \\
\hline 139. & $\cdot-$ \\
\hline 140. & \\
\hline & - \\
\hline 142. & $\ldots$ \\
\hline $\begin{array}{l}140 . \\
144\end{array}$ & - \\
\hline 145. & - \\
\hline 146. & - \\
\hline 147. & $\ldots$ \\
\hline 148. & - \\
\hline 149. & - \\
\hline 150. & 一 \\
\hline 151. & - \\
\hline 152. & - \\
\hline 153. & - \\
\hline 154. & - \\
\hline $15 \check{.}$ & - \\
\hline 156. & - \\
\hline 157. & - \\
\hline 158. & - \\
\hline 159. & - \\
\hline 160. & - \\
\hline 161. & 一 \\
\hline 162. & -- \\
\hline 163. & 一 \\
\hline 164. & 一 \\
\hline 165. & - \\
\hline 166. & - \\
\hline 167. & - \\
\hline 168. & - \\
\hline $\begin{array}{l}169 . \\
170\end{array}$ & -- \\
\hline & - \\
\hline 172. & - \\
\hline & \\
\hline
\end{tabular}

\section{Samlet}

Al- skatteder bel $\phi b^{\prime 2}$ )

$60 \quad 10,99$

$\begin{array}{ll}\mathbf{7 0} & \mathbf{1 0 , 7 8}\end{array}$

$35 \quad 10,31$

$60 \quad 10,00$

$55 \quad 10,00$

$55 \quad 9,97$

Rovbj. do. 60

do. pens, banearb. 70

Hovsl. aftægtsm. $\quad \mathbf{7 0}$

Rovbj. parcell. 30

Horsl. banearb. 35

Ø. L. husejer 81)

Rovbj. parcell. 41

Hovsl.

๑. L.

Rovbj.

ก. $\mathbf{L}$.

do.

do.

do.

Rovbj.

Ø. L.

Rovbj.

Ø. L.

Hovsl.

Hovsl.

do.

Kopsholt

Hovsl.

do.

do.

do.

do.

Rovbj.

Hovsl.

ø. L.

do.

do.

do.

Hovsl. sadler
$45 \quad 9,77$

do.

do.

9,66 har vær. opt. nej

$\mathbf{9 , 3 5}$ t. ja

9,08 d. nej

9,00 ? nej

$\mathbf{9 , 0 0}$ t. ja

9,00

8,70

$8, \overline{5} 5$

8,49

8,46

8,40

8,05

8,04

7,98

7,49

7,35

$\begin{array}{ll}45 & 7,35 \\ \text { flyttet } & 7,18\end{array}$

$\begin{array}{ll}\text { flyttet } & 7,18 \\ 60 & 7,13\end{array}$

$65 \quad 7,00$

7,00

$55 \quad 7,00$

$30 \quad 7,00$

30) 7,00

do. $\quad 30 \quad 7,00$

$40 \quad 7,00$

$40 \quad 7,00$

$65 \quad 7,00$

$45 \quad 7,00$

$70 \quad 7,00$

$55 \quad 6,80$

$45 \quad 6,64$

$40 \quad 6,20$

$45 \quad 6,20$ d. ja

t. ja ikke sidst

nyl. pr. u. nej

d. ja

d. ja

d. ja

d. ja

d. ja

t. ${ }^{*}$ ja

t. ja

d. ja

vistnok d.

d. ja

t. ja

t. ja

d. ja

t. ja

t. ja

stemte ikke

d. ja

t. ja

d. ikke sidst

t. ikke sidst

t. ja

d. ja

d. ja

d. ja

t. ja 


$\begin{array}{lcccc}\text { Navn } & \text { Bopæl } & \text { Samlet } & \\ & & \text { Al- } \text { skatte- } & \text { Sinde- } & \text { M } \phi \text { der } \\ \left.\text { der bel } \phi b^{12}\right) & \text { lag } & \text { han? }\end{array}$

\begin{tabular}{|c|c|c|c|c|c|c|c|}
\hline 175. & - & Rovbj. & aftægtsm. & 70 & 5,70 & d. & $\begin{array}{l}\text { syg, har } \\
\text { altid modt }\end{array}$ \\
\hline 176. & - & do. & do. & 70 & 5,40 & d. & ja \\
\hline 177. & - & $\emptyset . \mathrm{L}$. & banevogter & 50 & 5,40 & t. & ja \\
\hline 178. & - & Rovbj. & aftagtsm. & 70 & 5,40 & d. & ja \\
\hline 179. & -- & Jarup & smed & 35 & 5,40 & d. & ja \\
\hline 180. & - & do. & hanevogter & 50 & 5,40 & t. & ja \\
\hline 181. & -- & Hovsl. & banearb. & 40 & 5,40 & t. & ja \\
\hline 182. & - & Hovsl. & rentier & 70 & 5,40 & $? \mathrm{~d}$ & nej \\
\hline 183. & -- & Jarup & daglejer & 40 & 5,40 & $?$ & nej \\
\hline 184. & - & Hovsl. & banearb. & 35 & 5,40 & t. & ja \\
\hline 185. & - & do. & do. & 35 & 5,40 & t. & ja \\
\hline 181 . & -- & do. & aftægtsm. & 70 & 5,40 & & nej \\
\hline 187. & - & Jarup & $\begin{array}{l}\text { pagter og } \\
\text { komm.f. }\end{array}$ & 40 & 5,40 & t. & ja \\
\hline 188. & -- & Rovbj. & husejer & 45 & 5,25 & d. & ja \\
\hline 189. & - & $\emptyset$. L. & do. & 70 & 4,80 & d. & ja \\
\hline 190. & - & Rovbj. & do. & 60 & 4,50 & d. & nej \\
\hline 191. & - & do. & aftægtsm. & 70 & 4,20 & d. & $\mathrm{ja}$ \\
\hline 192. & -- & Jarup & daglejer & 65 & 4,20 & $?$ & nej \\
\hline 193. & - & Hovsl. & husejer & 70 & 4,03 & d. & ja \\
\hline 194. & - & Rovbj. & do. & 70 & 4,00 & t. & ja \\
\hline 195. & - & Jarup & arbejdsm. & 40 & 3,84 & d. & ja \\
\hline 196. & - & $\emptyset . \mathrm{L}$. & do. & 70 & 3. & d. & ja \\
\hline 197. & - & \multicolumn{6}{|c|}{ tjenestekarl,flyttet } \\
\hline 198. & 一 & Rovbj. & tjenestekarl & 25 & 3. & $?$ & \\
\hline 199. & - & Hovsl. & banearb. & 25 & 3. & t. & ja \\
\hline 200. & - & ø. L. & gartner & 30 & 3. & d. & ja \\
\hline 201. & - & Ø. L. & husmand & 40 & 3. & t. & ja \\
\hline 202. & - & Hovsl. & do. & 70 & 3. & $?$ & nej \\
\hline 203. & - & do. & do. & 70 & 3. & $?$ & nej \\
\hline 204. & - & $\emptyset . \mathrm{L}$. & arbejdsm. & 70 & 3. & & $\begin{array}{l}\text { ikke sidst, } \\
\text { nen før (t.). }\end{array}$ \\
\hline 205. & - & do. & \multicolumn{2}{|c|}{ fh. stationsf st.75 } & 3. & t. & ja \\
\hline 206. & - & do. & husmand & 35 & 3. & d. & ja \\
\hline 207. & 一 & Hovsl. & amtstjener & 45 & 3. & d. & ikke sidst \\
\hline 208. & - & Rovbj. & landmand & 24 & 3. & t. & ja \\
\hline 209. & - & do. & banearb. & 30 & 3. & t. & ja \\
\hline 210. & 一 & do. & do. & 28 & 3. & t. & ja \\
\hline 211. & - & $\emptyset . \mathbf{L}$. & bondes $\varnothing n$ & $\mathbf{3 5}$ & 3. & d. & ja \\
\hline 212. & 一. & do. & tjenestekarl & 75 & 3. & d. & ja \\
\hline
\end{tabular}




\begin{tabular}{|c|c|c|c|c|c|c|c|}
\hline & Navn & Bopæl & Stand & $\begin{array}{l}\text { Al- } \\
\text { der }\end{array}$ & $\begin{array}{l}\text { Samlet } \\
\text { skatte- } \\
\left.\text { bel } \phi b^{1 \Sigma}\right)\end{array}$ & $\begin{array}{l}\text { Sinde- } \\
\text { lag }\end{array}$ & $\begin{array}{c}\text { Møder } \\
\text { han? }\end{array}$ \\
\hline 213. & - & do. & bondesøn & 24 & 3. & d. & ja \\
\hline 214. & - & Hovsl. & arbejder & 60 & 3. & t. & ja \\
\hline 215. & - & Rovbj. & pens. banearb & .70 & 3. & t. & ja \\
\hline 216. & - & Hovsl. & tjenestekarl & 35 & 3. & d. & ja \\
\hline 217. & - & do. & aftægtsm. & 75 & 3. & $?$ & ikke sidst \\
\hline 218. & 一 & Jartp & arbejdsm. & 60 & 3. & $?$ & nej \\
\hline 219. & - & Horsl. & do. & 70 & 3. & t. & ja \\
\hline 220. & - & Rovbj. & tjenestekarl & 30 & 3. & d. & ja \\
\hline 221. & - & Hovsl. & postbud & 30 & 3. & t. & ja \\
\hline 222. & - & do. & tjenestekarl & 30 & 3. & t. $\mathrm{p}$ & olak ja \\
\hline 223. & -- & Rovbj. & aftægtsm. & 75 & 3. & d. & ja \\
\hline 224. & -- & Jarup & banearb. & 35 & 3. & t. & ja \\
\hline 225. & - & Hovsl. & bondes $\phi n$ & 25 & 3. & d. & ja \\
\hline 226. & - & Tyrholm & aftægtsm. & 75 & 3. & d. & ikke sidst \\
\hline 227. & - & Rovbj. & do. & 80 & 3. & d. & ikke sidst \\
\hline 228. & -- & Hovsl. & do. & 65 & 3. & t. & ja \\
\hline 229. & - & Jarup & arbejdsm. & 60 & 3. & d. & ja \\
\hline 230. & 一 & $\emptyset . \mathrm{I}$. & bondes $\varnothing n$ & 25 & 3. & d. & ja \\
\hline 231. & - & do. & aftagtsm. & 65 & 3. & d. & ja \\
\hline 232. & - & Rovbj. & husejer & 80 & 3. & $?$ & nej \\
\hline 233 & - & Hovsl. & arbejdsm. & 60 & 3. & $?$ & nej \\
\hline 234. & - & Rovbj. & tjenestekarl & 35 & 3. & d. & ja \\
\hline 235. & - & $\emptyset$. L. fattigg & . & 60 & 3. & d. & ja \\
\hline 236. & - & do. & tjenestekarl & 28 & 3. & d. & ja \\
\hline 237. & - & Hovsl. & pens. banearb. & .75 & 3 & t. & ja \\
\hline 238. & - & Hovsl. & nu gdr. & 28 & 3. & d. & ja \\
\hline 239. & - & Rovbj. & banearb. & 30 & 3. & t. & $\mathbf{j a}$ \\
\hline 240 . & - & $\emptyset . \mathrm{L}$. & landmand & 24 & 3. & t. & ja \\
\hline 241. & - & do. & do. & 30 & 3. & t. & nej \\
\hline 242. & - & Hovsl. & tjenestekarl & 30 & 3. & d. & ja \\
\hline 243. & - & do. & do. & 35 & 3. & d. & ja \\
\hline 244. & - & Jarup & do. & 35 & 3. & d. & ja \\
\hline 245. & 一 & do. & do. & 35 & 3. & t. & ja \\
\hline 246. & - & Rovbj. & do. & 35 & 3. & t. & nej \\
\hline 247. & - & Barlund & aftægtsm. & 60 & 3. & d. & ikke sidst \\
\hline 248. & 一 & Rovbjerg & husejer & 40 & 3. & d. & ja \\
\hline 249. & - & Hovsl. & arbejdsm. & 30 & 3. & t. & ja \\
\hline 250. & - & $\emptyset . \mathbf{L}$. & do. & 70 & 3. & d. & ikke sidst \\
\hline
\end{tabular}

*) Har været d., men børnene ved jernb. 
Inddeler man vælgerne efter deres skatteevne, viser det sig, at danskerne står stærkest i mellemstanden, hvorved her forstås JI. klasse og de f $\varnothing$ rste 2 grupper af III. klasse. Her stemte mellem 51,2 og 55,8 af samtlige på valglisten opf $\varnothing$ rte vælgere dansk. I I. klasse har man kun 42,9 \% af stemmerne og $i$ den laveste skattegruppe endog kun $33,3 \%$. Modsat står tyskerne stærkest i netop disse 2 grupper og har fået $57,1 \%$ af stemmerne i I. valyklasse og i den laveste skattegruppe 40,5 \%; mens de i mellemklasserne går ned fra $30,6 \%$ i II. valgklasse til 17,3\% i gruppen III B., for så igen at stige til 33,9 og 40,5\% i de 2 laveste skattegrupper.

De lavest beskattede, altså de i $\emptyset$ konomisk henseende svageste, har også været de svageste i kampen og modstanden. Det vidste man i forvejen, og tallene taler deres tydelige sprog herom. Men virkeligheden var alligevel en anden end den, tallene tegner for os. Om. en egentlig tyskhed, bevidst og rodfæstet, var der ikke tale; de tyske stemmer i de 2 laveste skattegrupper svandt da også ind til næsten ingenting ved folkeafstemningen i 1920. Kun ganske få af disse vælgere kan antages at have stemt tysk den 11. februar.

I. valgklasse havde ingen passive vælgere. Her var kampen hård, og alle måtte møde frem. I II. var der allerede $13,9 \%$ af valgerne, som blev hjemme, i III. A steg tallet til 23,2 og kulminerede i III. B med ikke mindre end $26,9 \%$.

Oversigt over valgerne inddelt $i$ skattegrupper.

\begin{tabular}{|c|c|c|c|c|c|c|}
\hline & I. valgkl. & II. valgkl. & III. $A^{1}$ ) & III. $\left.B^{2}\right)$ & III. C $\left.C^{3}\right)$ & III D. 4) \\
\hline d. & $42,9 \%$ & $5 \overline{5,5}$ & 51,2 & 55,8 & 40,3 & 33,3 \\
\hline t. & $57,1 \%$ & 30,6 & 25,6 & 17,3 & 33,9 & 40,5 \\
\hline pass. & 0 & 13,9 & 23,2 & 26,9 & 25,8 & 26,2 \\
\hline \multicolumn{2}{|c|}{ 1) samlet skattebeløb } & \multirow{2}{*}{\multicolumn{5}{|c|}{ 45,58-25,00 Mk. }} \\
\hline 2) & do. & \multirow{2}{*}{\multicolumn{4}{|c|}{$\begin{array}{r}24,05-11,42 \\
10,99-3,84\end{array}$}} & \\
\hline 3) & do. & \multicolumn{2}{|c|}{$10,99-3,84$} & & & \\
\hline ๑) & do. & $3 \mathrm{Mk}$ & Ialt 54 & one & er & skatte- \\
\hline
\end{tabular}

takst ( 3 Mk.), tager man aftægtsmænd og bondes $\varnothing n n e r$ (ialt 12), som socialt ikke hører hjemme $i$ denne gruppe, ud af oversigten, når man til ovenstående tal i III D. De nævnte 12 vælgere er opført i gruppen III A. 